Article

\title{
Can Consumers Understand Sustainability through Seafood Eco-Labels? A U.S. and UK Case Study
}

\author{
Alexis Gutierrez * and Thomas F. Thornton \\ Environmental Change Institute, Oxford University Centre for the Environment, South Parks Road, \\ Oxford OX1 3QY, UK; E-Mail: Thomas.thornton@ouce.ox.ac.uk \\ * Author to whom correspondence should be addressed; E-Mail: alexis.gutierrez@ouce.ox.ac.uk or \\ alexistgutierrez@gmail.com; Tel.: +44-1865-275848.
}

External Editor: Phoebe Koundouri

Received: 10 August 2014; in revised form: 14 October 2014 / Accepted: 23 October 2014 /

Published: 18 November 2014

\begin{abstract}
In the United States and the United Kingdom, over the last decade major retail chains have increasingly publicized their efforts to supply sustainably sourced and eco-labelled seafood. Debate exists over the extent of consumer demand for this product. Seafood eco-labels purportedly resolve the information asymmetry between producer and consumer, allowing consumers who care about sustainability to easily find and purchase these products. This paper discusses the idealized model of seafood eco-labelling in promoting sustainability and presents results of US and UK case studies based on consumer interviews and surveys, which found that consumers had often seen one or more seafood eco-labels. Two well-established eco-labels, dolphin-safe and organic, drove these rates of sustainable seafood awareness. These rates are interpreted in the context of consumer's understanding of sustainable. The Sustainable Seafood Movement's efforts to increase the supply of eco-labelled seafood and elaborate corporate buying policies for sustainable seafood are influencing consumer's recognition and purchase of certified sustainable seafood products. However, eco-labels are a means to communicate messages about sustainable fisheries to consumers, not an end. Efforts to educate consumers about eco-labels should be a component of ocean literacy efforts, which educate the public about the need for sustainable fisheries.
\end{abstract}

Keywords: consumers; eco-label; sustainable seafood; sustainable seafood movement 


\section{Introduction}

Consumers are supposedly in a position to "vote with their wallet", by supporting producers whom they know harvest in a more "environmentally friendly" or "sustainable" manner [1,2]. Marine capture fisheries are a public good that has historically suffered from overfishing, overcapacity and adverse impacts to bycatch species and the marine ecosystem [1-4]. Seafood eco-labels give interested consumers confidence that they are purchasing an environmentally friendly product. Eco-labels are a market based incentive if consumers' demand is sufficient to create a signal in the market and thus incentivize sustainable fisheries $[1,5,6]$.

This model is based on the following logic, as depicted in Figure 1. First, there are consumers who are aware and care about the environment and want to buy "sustainable" or "environmentally responsible" goods. Second, these consumers have clear information about the goods they are buying. Third, a label or mark, such as an eco-label, provides a clear signal of environmental sustainability that enables consumers to demonstrate demand for these products in the marketplace. Fourth, the more consumers that purchase an eco-labelled product, the more collective demand or "pull" is created for retailers to provide such products. Fifth, the "pull" from retailers to buy certified sustainable product incentivizes fishermen to modify their practices to be more sustainable.

Figure 1. Model of consumers' role in eco-labelling.

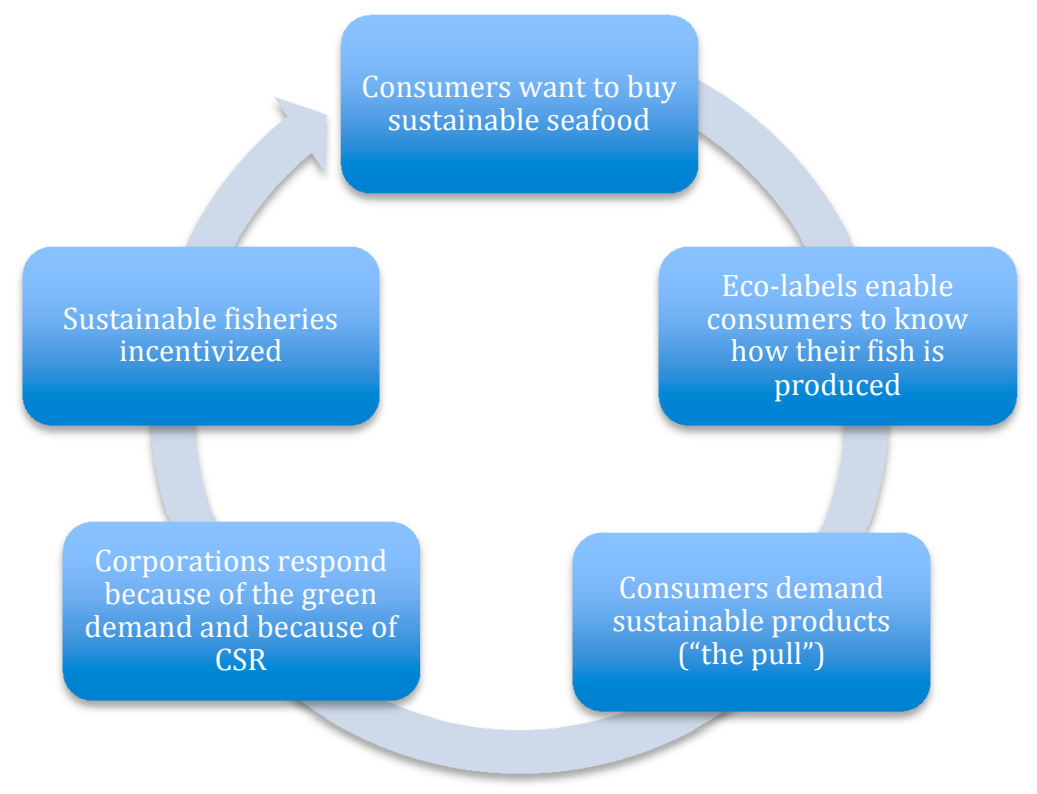

One way that suppliers have found to demonstrate their product is sustainably produced is by participating in certification programs, such as the Marine Stewardship Council (MSC) or fishery improvement projects [7]. Consumers then have a greater supply of certified sustainable seafood from which to buy; the more they buy the more they incentivize other fisheries to become certified.

Despite this apparent logic, when each step of this telelogical model is examined in the light of peer-reviewed literature, weaknesses are exposed. If this logic, or causal model, does not motivate consumers in the real world, what does? We examine this question, through an analysis of the literature and consumer interviews and surveys in the U.S. and UK marketplace. 


\subsection{Assumption One-Consumer Awareness}

Before we can assume consumers want to buy sustainable seafood, we need to establish their awareness and the importance they place on addressing seafood sustainability issues such as overfishing, habitat impacts, and bycatch of endangered and protected species. Recent studies in Europe indicate a low awareness of these issues. Pieniak et al. surveyed 3213 European consumers in 2008 about their knowledge of six commonly understood facts about wild-capture fish and aquaculture. Six true/false questions were asked covering topics such as prevalence of farmed v. wild fish in the European market, mercury content in farmed fish v. wild fish, the use of antibiotics in farmed fish and, level of imports in the European products. Overall respondents' knowledge was very low with only two out of six questions correctly answered by $50 \%$ or greater of the total participants surveyed [8].

Further, some studies indicate people do not see oceans issues as very important. Potts et al. surveyed 7000 European residents in 2010/2011 about the importance of the ocean to them [9]. When asked how concerned respondents were about each of the following issues - cost of living, health and education, the economy, pollution, affordable energy, poverty, climate change, terrorism, ocean health, species loss and safe and available food, the results showed that ocean health ranked third from the bottom of 11 issues with only $46 \%$ of the respondents indicating that it was important or very important. Further, when asked to indicate whether an activity was seen as a threat to the ocean, fisheries were ranked fifth from the bottom (between shipping and new and introduced species), with industry pollution, litter, oil and gas extraction, climate change, ocean acidification, and shipping seen as higher priorities.

However, some segment of consumers are interested in sustainable seafood products. For example, the Monterey Bay Aquarium's Seafood Watch card has been distributed over 40 million times and their smartphone app has been downloaded nearly a million times [10]. While, this does not translate directly to sales, it does demonstrate a general interest and awareness about seafood sustainability issues by an increasing segment of consumers.

\subsection{Assumption Two-Eco-Labels Empower}

Secondly, eco-labels resolve the information asymmetry between the seller and buyer of a good by providing information to the buyer on how the product was produced [1]. Consumers theoretically can trust that eco-labelled products are produced in a sustainable manner as opposed to un-labelled products. However, some studies indicate if too much information is presented it can confuse and in some cases cause consumers to avoid purchases. For instance, Hallstein et al. evaluated customer's response to a traffic light labelling scheme (green means buy, yellow means buy with caution and red means avoid buying) in a regional supermarket chain in the San Francisco Bay Area of California [11]. Examining sales before, during and after the transition to the traffic light scheme (coupled with a posted low mercury list), they found a statistically significant $15.3 \%$ decline in overall seafood sales, largely driven by a statistically significant $41.3 \%$ decline in the sale of yellow labelled seafood on the mercury safe list [11]. While the yellow labelled product on the low mercury list was intended to indicate that the consumer should be cautious about purchasing this seafood product but not necessarily avoid it altogether, many consumers appear to have treated the product like a red labelled product and avoided purchase [11]. There was no statistically significant difference in the sales of red or green labelled seafood after the 
transition. This study found that the labelling of products green, yellow or red only changed consumer behaviour when the product was labelled yellow. Thus, despite the logic model indicating that labels resolve the information asymmetry, in some cases consumers are not interpreting the labels and associated information the way retailers and their environmental non-governmental (ENGO) partners anticipated.

Uchida et al. also looked at the interaction of information with consumers' preference for eco-labels [12]. He found that when consumers have an existing baseline of information and additional information is provided, as long as that information is deemed as credible or interesting, it improves the consumer's perception of eco-labels. For example, when consumers were told that fish stocks worldwide were decreasing as a result of overfishing and then given United Nations Food and Agriculture Organization (FAO) information about stock exploitation they deemed credible, they placed a higher value on the eco-label. Uchida et al.'s (2014) work highlights the many factors - country of origin, news of stock status, wild v. farmed - that can influence consumer's perceptions of eco-labels.

The proliferation of eco-labels has also caused concern about heightening consumer confusion [13-16]. Ben Youseff and Abderrazak (2009) used a vertical differentiation model to study the environmental effects and competition of a market with multiple eco-labels. The level of information varies by case. In the first case, information is complete and in the second case the information is incomplete. In the second case, consumers use price as a signal for environmental quality. They found when information is complete a second eco-label in the market improves the environmental quality of the eco-labelled goods, provided the environmental quality the firm advertised is actually in the product. However when the information is incomplete, firms have an incentive to diminish the environmental quality. As a result, consumers increasingly don't factor the label into their purchasing decision. They conclude that information is very important when there are multiple labels [17].

Brecard et al. also looked at consumer confusion related to multiple eco-labels in the market [18]. Their analysis differs from Ben Youseff in that it includes an unlabelled product and assumes that consumers believe the eco-labelled products indicate the same level of environmental quality, but differ horizontally, that is to say in how close or far the product is to their ideal product. They use a double differentiation framework, which assumes that consumers perceive a label as a sign of quality compared to an unlabelled product but are not able to distinguish the environmental quality associated with each label. They model pricing strategies for three firms that provide a health label, an eco-label and an unlabelled product. They find that the firm providing the eco-labelled product is weakened by the consumer confusion, strict labels hurt the unlabelled product, and the firm selling the health labelled product benefits. Based on their model, they find that over time the unlabelled products will be pushed from the market because they will be perceived as of a lesser quality [18].

In all of these studies, information is key to empowering consumers. However, it is not clear that a one-size-fits-all strategy will empower all consumers sufficiently to allow them to understand and use eco-labels to make more informed purchases. As Eden et al. argue: labels and assurance schemes instead of "unveiling connections" between consumers and the producers may have just inserted themselves as another link in the complex production chain [19]. The consumer as an active agent may accept a product as sustainable without really knowing how his or her purchase contributes to sustainability as a set of on-going environmental, economic, and social processes. As Eden et al. state, "This is problematic because it is precisely this unthinking approach that so many have criticized: the solution of assurance itself can therefore become a problem for assurance [19]". 
Eco-labels may not resolve the information asymmetries they were designed to mitigate without the proper context and understanding by consumers. Research on consumer demand can shed light on how and under what circumstances consumers respond to eco-labels.

\subsection{Assumption Three-Consumer Demand}

Several willingness-to-pay studies have been conducted to determine consumer demand for eco-labelled seafood. Initially, much of this research focused on whether consumers would be willing to pay more for an eco-labelled product as the assumption was that producing an environmentally friendly product would cost more. Roheim and colleagues studied consumers' willingness to pay and found varying results depending on the country and nature of the survey [20-23]. For instance, Johnston and Roheim looked at whether consumers would switch away from their favourite species if it were not eco-labelled to less favoured but eco-labelled species, given varying price levels [22]. Fifteen hundred households were surveyed by mail with a thirty-one per cent response rate. Participants chose between eco-labelled and non-eco-labelled fresh swordfish, flounder, salmon, and cod at varying prices and where certification indicated the fish were not from an overfished fishery. The study noted whether the species was the respondent's favourite or overfished. Results indicated consumers were not willing to sacrifice a favourite fish, with respect to taste, in order to purchase a less-favoured fish that had a "no-overfishing" eco-label [22].

The aforementioned studies typically have been conducted in experimental settings. In the marketplace, the evidence of consumer demand is mixed. Roheim et al. looked at aggregated scanner data for metropolitan London to establish whether a price premium existed for Marine Stewardship Council (MSC) labelled Alaskan pollock [23]. They argue that establishing the existence of a price premium assists in the evaluation in the effectiveness of eco-labelling as a market-based incentive, as fishermen need to perceive market benefits, either in the form of a price premium or market access, in order to justify the costs of entering a certification scheme. Roheim et al. analysed the volume and dollar sales by SKU for over 400 frozen processed seafood products aggregated across London metropolitan supermarkets on a weekly basis for 65 weeks (2007-2008) to determine that 24 pollock products allowed for comparative analysis. Twelve of the twenty-four products were MSC labelled. Analysis showed 3.03 million units of 12 non-MSC labelled products sold versus 3.3 million units of the 12 MSC labelled products sold during the same period. A 14.2\% price premium on those MSC-labelled processed frozen pollock products exists relative to non-MSC labelled frozen pollock products, after taking into account brand, product form, package size and process form (Roheim, Asche et al. 2011). This study demonstrated that there was a higher demand for MSC product than non-MSC; however, the analysis did not control for special offers on these products. Sogn-Grundvag et al. also looked at MSC versus other environmental labels like "line caught" and found that both products had a price premium [24]. The Hallstein study also used scanner data [from barcoded products] to demonstrate that in some cases demand for labelled product declines if the messaging is confusing [11]. Overall, the results are mixed as to whether there is a universally strong signal from consumers for eco-labelled products across genders, age, income groups and geographic location [25-27]. 


\subsection{Assumption Four-Corporations and Corporate Social Responsibility}

The fourth assumption underlying the idealized eco-label feedback loop is that retail corporations respond to consumer demand for eco-labelled seafood as well as from a sense of corporate social responsibility. As discussed in the previous section, consumer demand is not strong enough alone to cause retailers to develop sustainable seafood policies and offer more eco-labelled seafood products. Gulbrandsen argues that ENGOs's pressure/encouragement on large corporations to adopt these certification schemes, has facilitated the growth of these certification schemes more than consumer demand [5]. Several ENGO-corporate partnerships, such as World Wildlife Fund and Walmart, have developed over the last decade. These partnerships fostered multiple corporate commitments, which have spurred competitors to adopt similar commitments. For instance, in 2006, Walmart announced it would only stock MSC certified marine capture products within the next three to five years in the U.S. market [28]. While this corporate commitment was broadened in later years to state MSC certified "or equivalent", Walmart nonetheless is working to ensure that seafood in their supply chain is coming from sustainable sources. Walmart's 2011 Sustainability report indicated that $73 \%$ of the total pounds of wild fish and farmed seafood at Walmart U.S. and Sam's Club was certified by MSC, the Best Aquaculture Practices or equivalent certification. Walmart's commitment has incentivized its competitors to adopt similar commitments [29].

Corporations are motivated to adopt a seafood sustainability policy as part of their corporate social responsibility goals given that: (1) They need to stay competitive within the grocery industry; (2) Buying seafood from sustainable sources ensures long-term access to product; (3) Potential ENGO boycotts make grocery chains wary of risking their reputation and brand [1,30,31]. To this end, supermarkets like the UK's Sainsbury's promote their MSC labelled seafood products and celebrate successes, such as their January 2012 milestone of reaching 100 different MSC labelled products. Consumers have as a result an increasing abundance and diversity of certified seafood product to choose from. Thus, ENGO-corporate partnerships efforts that have developed with the growth of the Sustainable Seafood Movement may be changing consumers' seafood choices and nudging consumers to choose certified seafood product more than the demand originating with consumers $[5,32]$.

\subsection{Assumption Five-Sustainable Fisheries Incentivized?}

The ultimate goal of this conceptual model of sustainability behaviour is to incentivize sustainable wild capture fisheries. Of all wild capture marine eco-labels, the MSC has likely been reviewed the most to determine its effectiveness in rebuilding marine fish stocks [33-36]. Froese et al. reviewed several fisheries certified by the MSC and Friends of the Sea (FOS). For stocks with available information, and defining overfished as stock size reduced below maximum sustainable yield, they found that $19 \%$ of the FOS and $31 \%$ of the MSC fisheries were overfished or subject to overfishing [33]. Agnew et al. presented a rebuttal to this analysis. Using the more traditional definition of overfishing as biomass $50 \%$ below maximum sustainable yield, they found that none of the $45 \mathrm{MSC}$ stocks with sufficient data for analysis were overfished [37]. Thus, debate over the effectiveness of seafood certification processes, such as MSC, in improving the sustainability of fish stocks is far from resolved. 
Nevertheless, the growth of eco-labels and seafood sourcing policies has led members of the seafood processing industry to improve the sustainability of their operations and to publicly communicate these improvements. Similarly, the growth of fishing industry led initiatives, such as Gulf SeafoodTrace, or ENGO-industry partnerships, such as GulfWild, suggest that the fishing industry is working to improve the sustainability of their product and publicizing it to consumers, buyers and the general public.

A critical assessment of the literature on the consumer's role in incentivizing sustainable seafood through their purchase decisions questions the validity of this model and suggests that the emphasis on consumers driving the process is inaccurate [5]. Instead, actors in the Sustainable Seafood Movement, like ENGOs, foundations, fishing interests and retailers have been the major contributors to the increase in supply of sustainable seafood and improved fisheries management practices [38]. If this is true, why is seafood certification still characterized as "consumer-driven" $[39,40]$ ? And what roles do consumers play in shaping sustainable seafood certification and associated sourcing policies?

These questions are addressed below through a detailed study of consumers' awareness of seafood eco-labels in Washington, DC and Southeast England. In addition, we examine consumers' articulation of what sustainable seafood means, and from the results of these investigations develop recommendations as to what role consumers could play in incentivizing more sustainable fisheries.

\section{Methods}

The United States and United Kingdom were chosen as case studies due to their common language, comparable consumer profiles, highly developed seafood markets, and the presence of seafood eco-labels on products in major urban retail outlets in both countries. Washington, DC and Oxford and London, England were selected as study sites. The research was carried out in several iterative steps. Starting in July 2012, 14 semi-structured interviews, lasting 10-15 min, of Southeast England Farmers' Market shoppers were conducted and transcribed. From this a more structured interview was developed and administered to 14 respondents at a Washington, DC Farmers' Market in October 2012, lasting 5-10 min. Respondents were those intercepted at the respective markets who were willing to be interviewed. Farmer's markets were selected as the initial interview sites since those who shop at farmer's markets are more likely to think about where their food comes from. These particular markets were selected based on the willingness of organizers to permit interviews on site. Interviews focused on shopping habits, the expectations consumers had of their retailers and what "sustainable" meant to them.

Surveys of wet counters, frozen and canned seafood displays in major supermarkets were conducted in Washington, DC and London in 2012 and 2013 to identify the most common eco-labels and environmental claims (e.g., sustainably caught, wild-caught, responsibly caught). At least one store was surveyed from every major supermarket chain in the area.

Using the 2012 qualitative surveys as a basis, a largely quantitative survey was developed and administered in April and May 2013. Eighty-six consumers in Washington, DC and 80 consumers in London, England were surveyed about their shopping habits related to seafood products. The recruitment criteria were as follows: the consumer ate seafood, the consumer was alone, and he/she spoke English. Similar to Hanss et al. consumers were surveyed in public places such as in front of grocery stores, at local parks, and near subway stations in each city [41]. Surveys were conducted in the morning, the middle of the day and in the evening during the week and weekends over the course of two weeks in 
each city. Consumers were shown the questions on an iPad Quicktap app, allowing the respondents to see the question and answers. All statistical analysis was conducted in SPSS 21. All qualitative data was coded using NVivo 10. An inductive approach was employed, wherein key themes were drawn from the open-ended responses. All the open-ended responses were transcribed and the texts were analysed several times to identify major themes.

\section{Results and Discussion}

This results section is presented in two parts. The first part focuses on the quantitative results from the spring 2013 survey in Washington, DC and London, England. The second part is the qualitative analysis of the 2012 interviews and 2013 surveys, specifically focusing on the question related to what sustainable means to the respondent in the context of food purchases.

\subsection{Consumer Characteristics from All Surveys}

Table 1 presents a summary of the consumer characteristics from all the interviews conducted in Washington, DC and Southeast England in 2012 and 2013.

Table 1. U.S. and UK consumer characteristics.

\begin{tabular}{|c|c|c|c|c|}
\hline Variable & Oxford, UK & Washington, DC & Washington, DC & London, UK \\
\hline Number of Participants & 14 & 14 & 86 & 80 \\
\hline Female Respondents & $12(86 \%)$ & $8(57 \%)$ & $48(55.8 \%)$ & $43(53.8 \%)$ \\
\hline Age Range & $\begin{array}{l}26-67 \\
\text { mean }=45.64\end{array}$ & $\begin{array}{l}22-78 \\
\text { mean }=46.29\end{array}$ & $\begin{array}{l}18-77 \\
\text { (Three non-responses) } \\
\text { mean }=40.28\end{array}$ & $\begin{array}{l}\text { 17-73 years } \\
\text { (Two missing responses) } \\
\text { mean }=36.38\end{array}$ \\
\hline $\begin{array}{l}\text { Undergraduate } \\
\text { degree or higher }\end{array}$ & $86 \%$ & $93 \%$ & $75 \%$ & $\begin{array}{l}75 \% \text { (Education levels } \\
\text { based on tUK Office of } \\
\text { Qualifications } \\
\text { and Examination } \\
\text { Regulations; } \\
\text { Missing one response) }\end{array}$ \\
\hline Median Income & $\begin{array}{l}22 \mathrm{k}-38 \mathrm{k} \text { USD } \\
\text { (Two non-responses) }\end{array}$ & $\begin{array}{l}85 \text { k USD (Two non-responses, } \\
\text { individual income was asked } \\
\text { instead of ranges for this survey) }\end{array}$ & $\begin{array}{l}\text { 61-80 k USD } \\
\text { (12 non-responses) }\end{array}$ & 30-60 K USD \\
\hline Political Affiliation & $50 \%$ Green Party & $\begin{array}{l}72 \% \text { Democrat; } 14 \% \text { Green Party; } \\
14 \% \text { Independent }\end{array}$ & $\begin{array}{l}51.2 \% \text { Democrat; } 20.9 \% \\
\text { Independent } \\
\text { (Three non-responses) }\end{array}$ & $\begin{array}{l}60 \% \text {-None; } \\
16.3 \% \text { Labour } \\
\text { (Two non-responses) }\end{array}$ \\
\hline Religious Affiliation & $\begin{array}{l}43 \% \text { None } \\
21 \% \text { Christian }\end{array}$ & $57 \%$ None $14 \%$ Christian & $\begin{array}{l}34.9 \% \text { None } 31.4 \% \text { Christian } \\
\text { (Three non-responses) }\end{array}$ & $\begin{array}{l}37.5 \% \text { Christian } \\
36.8 \% \text { None } \\
\text { (One non-response) }\end{array}$ \\
\hline Religiously Active & $\begin{array}{l}36 \% \text { No Response; } \\
29 \% \text { Inactive }\end{array}$ & $93 \%$ Inactive & $\begin{array}{l}52.3 \% \text { Inactive } \\
\text { (Four non-responses) }\end{array}$ & $\begin{array}{l}66.3 \% \text { Inactive (One non- } \\
\text { response) }\end{array}$ \\
\hline
\end{tabular}

Resources were not available to conduct a representative sample, so a street intercept survey was conducted in public places. In comparison to census data in both cities, our survey results are skewed 
towards more educated and wealthy individuals than the average in both cities. That said the findings of this study are informative for those interested increasing consumer knowledge and understanding of sustainable fisheries through eco-labels.

\subsection{Results from Structured Surveys in London and Washington, DC}

Consumers in both cities were asked several questions about their seafood purchasing habits, as well as to indicate the importance of various product attributes. The majority of the respondents in both cities was the primary shopper (77.5\% in London, $84.9 \%$ in Washington, DC) in their household and bought seafood frequently (55.0\% in London and $40.7 \%$ in Washington, DC).

Respondents were asked about the importance of several seafood product attributes (freshness, price, environmental impact, location/origin, health benefits, and brand). These questions were also used in the Potts/Brennan survey of UK seafood shoppers [6]. The scale used ranged from Very Important, Important, Moderately Important, Of Little Importance, to Unimportant. Rank analysis indicates that freshness of seafood is the most important attribute and brand is the least in both cities. Environmental impact of product was the third most important attribute in both cities, above price.

\subsubsection{Labels Seen and Purchased}

In the Washington, DC sample $87.2 \%$ of the respondents had seen and $76.7 \%$ had purchased one or more seafood products with an eco-label or environmental claim. In the London, England sample 72.5\% had seen an eco-label or an environmental claim and 60.0\% had purchased one or more of these products. Binominal tests indicate that respondents in the Washington, DC sample are significantly likely to have seen and purchased one or more seafood products with an eco-label or environmental claim $(p<0.001)$. The London sample is only significant for those who have seen eco-labels or environmental claims, but not those that have purchased these products.

In the Washington, DC sample the most recognized label was organic, followed by dolphin-safe, wild-caught, and MSC (see Table 2). The MSC label was seen by $17.4 \%$ of the Washington, DC respondents, which is slightly lower than the Marine Stewardship Council's U.S. survey results. Their internet survey of 600 U.S. consumers found that 21\% reported having previously seen the MSC label [42].

The recognition ranking differed for the London sample (see Table 2). Dolphin-safe was the most seen, followed by organic, RSPCA (which is a UK only label), and then MSC. In the London sample, as many people had seen no label $(n=22$ out of 80$)$, as had seen MSC ( $n=22$ out of 80$)$. According to MSC's UK 2012 consumer research $(n=600), 31 \%$ of the respondents had an awareness of the MSC label [42]. Here, the awareness level was $27.5 \%$.

With respect to purchases, $72.5 \%$ of the London sample had seen one or more eco-labels, and $60.0 \%$ had purchased products with such labels. The ranking of the top three was the same between seen and purchased. As would be expected, those who reported seeing an eco-label or environmental labelling had a significant, positive correlation to those who purchased one (Pearson correlation $=0.754, p=0.01$ ). (It should be noted for London, unlike DC, some consumers said they purchased a label they had not indicated seeing. This was due to consumers not realizing until the reading of the question that some brands they regularly purchase, e.g., Young's or Coop, carry such a label). 
When the dolphin-safe and organic responses were removed from the samples, the recognition of one or more labels dropped. For Washington, DC, $80.2 \%$ of the respondents had seen one or more of the labels (excluding dolphin-safe) and 69.8\% had purchased one or more of the labels (excluding dolphin-safe). If dolphin-safe is excluded from the London sample, then $65.0 \%$ of the respondents had seen one or more of the labels and $51.3 \%$ had purchased one or more of the labels.

If organic is excluded, then $69.8 \%$ of Washington, DC respondents report having seen one or more of the labels and $53.5 \%$ of the respondents report having purchased one or more of the labels. In London, $66.3 \%$ of the respondents report having seen one more of the labels if organic is excluded. And $57.5 \%$ of the London respondents report having purchased one or more of the labels, if organic excluded.

Table 2. The most recognized label was organic, followed by dolphin-safe, wild-caught, and MSC in Washington, DC.

\begin{tabular}{|c|c|c|}
\hline Variable & Washington, DC $(n=86)$ & London, England $(n=80)$ \\
\hline \multirow{2}{*}{ Dolphin Safe } & Seen $44(51.2 \%)$ & Seen $34(42.5 \%)$ \\
\hline & Purchased $32(37.2 \%)$ & Purchased $28(35.0 \%)$ \\
\hline \multirow{2}{*}{$\begin{array}{c}\text { Marine Stewardship } \\
\text { Council }\end{array}$} & Seen $15(17.4 \%)$ & Seen $22(27.5 \%)$ \\
\hline & Purchased $11(12.8 \%)$ & Purchased $17(21.3 \%)$ \\
\hline \multirow{2}{*}{$\begin{array}{c}\text { Coop Responsibly } \\
\text { Sourced (UK ONLY) }\end{array}$} & & Seen $12(15.0 \%)$ \\
\hline & & Purchased $11(13.8 \%)$ \\
\hline \multirow{2}{*}{ Organic } & Seen $63(73.3 \%)$ & Seen $29(36.3 \%)$ \\
\hline & Purchased $56(65.1 \%)$ & Purchased $20(25.0 \%)$ \\
\hline \multirow{2}{*}{$\begin{array}{c}\text { Friends of the Sea } \\
\text { (UK ONLY) }\end{array}$} & & Seen $4(5.0 \%)$ \\
\hline & & Purchased $1(1.3 \%)$ \\
\hline \multirow{2}{*}{$\begin{array}{c}\text { Young's Fish for Life } \\
\text { (UK ONLY) }\end{array}$} & & Seen $6(7.5 \%)$ \\
\hline & & Purchased $7(8.8 \%)$ \\
\hline \multirow{2}{*}{$\begin{array}{c}\text { RSPCA } \\
\text { (UK ONLY) }\end{array}$} & & Seen $24(30.0 \%)$ \\
\hline & & Purchased $18(22.5 \%)$ \\
\hline \multirow{2}{*}{$\begin{array}{c}\text { Alaska Seafood } \\
\text { (US ONLY) }\end{array}$} & Seen $5(5.8 \%)$ & \\
\hline & Purchased $4(4.7 \%)$ & \\
\hline \multirow{2}{*}{$\begin{array}{c}\text { Sustainably Caught } \\
\text { (US ONLY) }\end{array}$} & Seen $12(14.0 \%)$ & \\
\hline & Purchased $11(12.8 \%)$ & \\
\hline \multirow{2}{*}{$\begin{array}{c}\text { Responsibly Farmed } \\
\text { (US ONLY) }\end{array}$} & Seen $9(10.5 \%)$ & \\
\hline & Purchased $6(7.0 \%)$ & \\
\hline \multirow{2}{*}{$\begin{array}{l}\text { Wild Caught } \\
\text { (US ONLY) }\end{array}$} & Seen $18(20.9 \%)$ & \\
\hline & Purchased $15(17.4 \%)$ & \\
\hline \multirow{2}{*}{ None } & Seen $11(12.8 \%)$ & Seen $22(27.5 \%)$ \\
\hline & Purchased $20(23.3 \%)$ & Purchased $32(40 \%)$ \\
\hline \multirow{2}{*}{ Seen a Label or more } & Seen $75(87.2 \%)$ & Seen $58(72.5 \%)$ \\
\hline & Purchased 66 (76.7\%) & Purchased $48(60.0 \%)$ \\
\hline
\end{tabular}

If the dolphin-safe and organic responses are both excluded, then consumer recognition of one or more labels drops to $40.7 \%$ in Washington, DC and 52.5\% in London. Those that report purchasing one or more of the remaining labels drops even further to $30.2 \%$ in Washington, DC and $43.8 \%$ in London, 
England. Thus, reported purchase levels are much smaller when the dolphin-safe and organic labels, which have been established longer, are removed.

\subsubsection{Impact of Information on Willingness to Purchase}

With the proliferation of seafood eco-labels, information about those labels becomes increasingly important for consumers to be able to make informed choices [17]. This survey looked at the effect of providing information about a seafood eco-label on a consumer's willingness to buy it. In each city a subset of respondents was given information about the MSC label and another subset was not. These respondents were then asked whether they would be more willing to buy an MSC labelled product.

The MSC data was pooled across both countries in order to have sufficient sample size to analyse. Using a general linear model $\left(R^{2}=0.127\right.$, se $\left.=0.3940\right)$, which controlled for income and frequency of seafood purchases, showed that the presence of an MSC label was a significant variable $(p<0.005)$ in determining whether the respondent was willing to buy the seafood product.

This finding suggests that explaining what the MSC label represents can increase respondents' likeliness to buy these labelled products. These results must be caveated, however, as hypothetical biases can exist wherein respondents may give the social acceptable response versus what they will actually do. Still, these findings comport with those of Uchida et al. who analysed the influence of information on consumer's perceptions of eco-labels in Japan. They found that when additional information is given to consumers about fisheries status that is deemed credible it increases the preference for eco-labels [12]. However, they did not test for whether it was the content or the source of the information that was influential.

\subsubsection{Concern about Sustainability}

The survey contained several questions related to respondents' view of the importance of sustainability in their purchases. Using a Likert scale from very important (=5) to unimportant $(=1)$, the average response in both cities regarding the importance of sourcing their food from sustainable sources was between moderately important to important (London $=3.8, \mathrm{sd}=0.76$; Washington, $\mathrm{DC}=3.9, \mathrm{sd}=1.0$ ). Similarly, they indicated that shopping at retailers that care about how their farmers and fishermen produce their products was moderately important (London $=3.9, \mathrm{sd}=0.73$; Washington, $\mathrm{DC}=4.0$, $\mathrm{sd}=0.99)$. And finally, they indicated that their food purchases were moderately important in influencing retailers' buying policies (London $=3.5, \mathrm{sd}=0.86$; Washington, $\mathrm{DC}=3.6$; $\mathrm{sd}=1.0$ ).

\subsubsection{Knowledge and Trust}

The survey concluded with questions on consumer's knowledge of who manages their commercial fisheries, where they get their information on food production, and whom they trust to ensure that the food they eat is sustainable. While the respondents demonstrated a high awareness of one or more eco-labels, $50 \%$ of the respondents in both cities did not know which government agency managed their country's commercial fisheries.

Respondents were asked whether they placed their trust in retailers, producers or both to ensure that the food they eat is sustainable. The majority of respondents in Washington, DC indicated that they placed their trust in both the retailer and the producer, whereas in London there was a tie between both 
the retailer and the product. Finally, when asked who they trust the most to ensure that their food is sustainable, consumer groups and environmental groups were most trusted in Washington, DC (Figure 2) and consumer groups and their own judgment in London (Figure 3). Government and retailers were the least trusted in both cities.

Figure 2. U.S. responses on the most trusted organization.

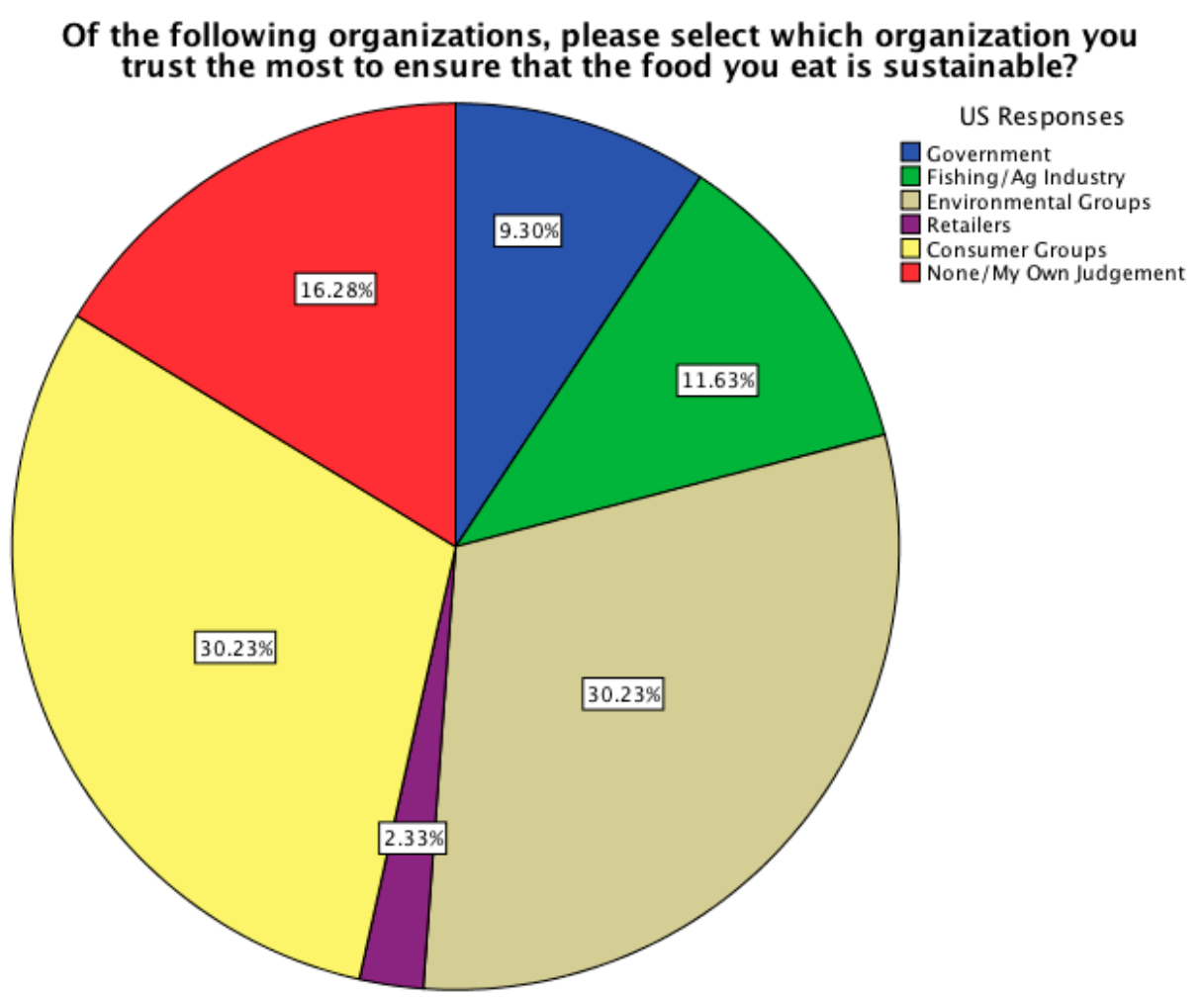

Figure 3. UK responses on the most trusted organization.

Of the following organization, please select the one you most trust to ensure the food you eat is sustainable?

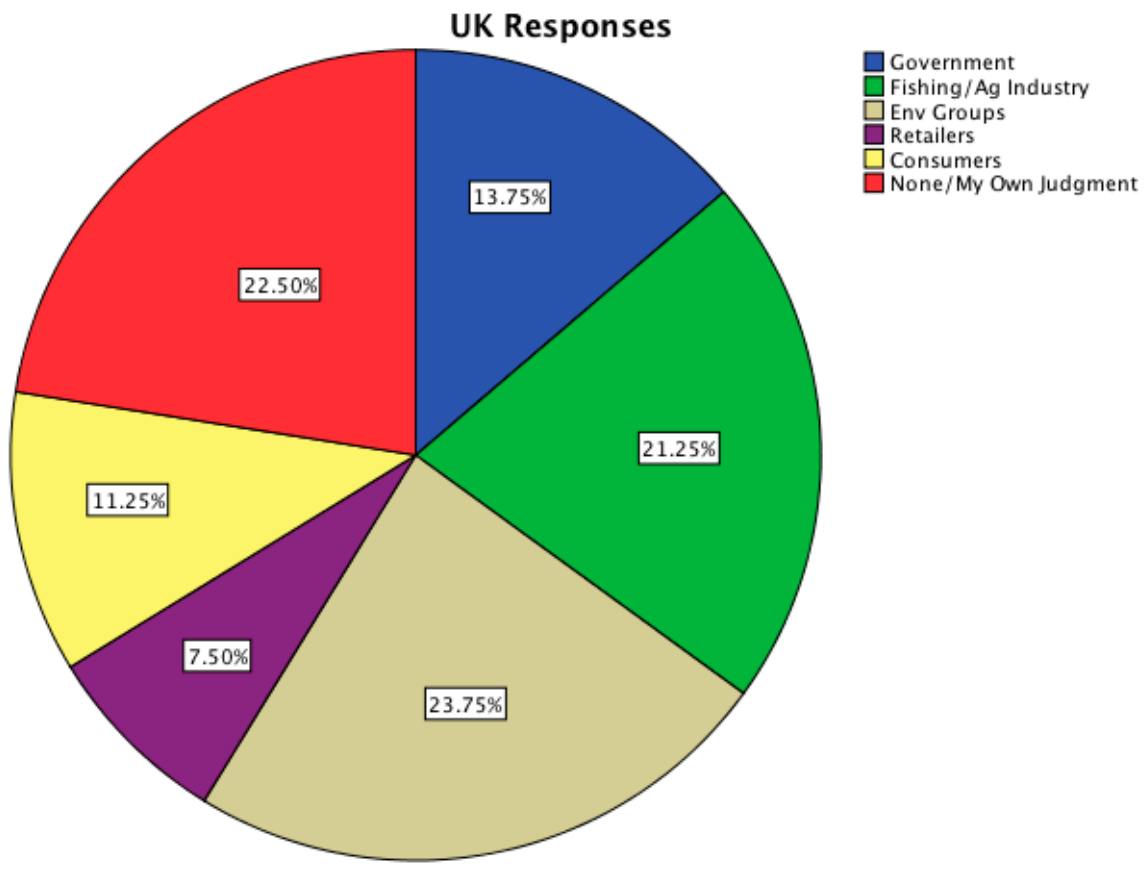




\subsection{Qualitative Analysis}

This section focuses on the qualitative analysis of responses to the question "what does the word sustainable mean to you?", which was included in all of the interviews and surveys $(n=194)$. Given that "sustainable" is increasingly used in eco-labelling and other environmental claims on packaging, in seafood buying guides issued by ENGOs, and in retailers' materials on their sustainable seafood sourcing policies, this question probed what consumers are interpreting sustainable to mean.

Using NVivo 10, an inductive text analysis was conducted and nine themes were identified. These themes were not distinct, but rather overlapping. The themes were ranked from most referenced to least referenced by consumers - environmental responsibility, time, perpetual availability, use, production, avoiding degradation, balance, quality/reliability and I don't know.

\subsubsection{Environmental Responsibility}

The vast majority of the respondents expressed some level of responsibility to the environment and/or future generations when describing the word sustainable. This environmental responsibility applied to either themselves, the producer or in some cases both. Those who expressed responsibility from a personal standpoint emphasised how people should treat the environment and what personal actions, such as consumption choices, should be influenced. As one East Oxford Farmers' Market respondent said: "[sustainable means] doing our best not to damage, basically, and with awareness. Consuming with awareness. Acting towards the environment. It's a lot to do with respect and awareness". A London respondent stated, "it means ensuring something is sustainable ... whatever I do makes an impact the next day if I don't buy a sustainable product I feel like I'm cheating the environment". Others echoed this conception by talking about the importance of knowing where your food comes from and that "people must care what they eat".

Several respondents in both cities highlighted environmental responsibility in terms of future generations. As one respondent remarked: "[sustainable means] the product will be there for my children and my children's children, ad infinitum". That is, that one generation should not deplete or degrade valuable resources whether plant, animal, terrestrial or marine.

However, this responsibility to the earth does not negate its use; in fact most of the conceptualizations of sustainability feature a very active sense of use. One respondent described sustainable as "you use the environment so that you get the most effective outcome without destroying everything". Implicit in these descriptions is the concept of the consumer and producer acting responsibly towards the environment, but how the consumer acts responsibly is typically discussed in the context of use or purchase, whereas the producer's role is framed in terms of the types of production methods. Captured also within this theme of environmental responsibility is the obligation for production to be safe, as numerous respondents stated that sustainable means "eco-friendly" or "environmentally safe".

\subsubsection{Time}

Time was a theme that surfaced repeatedly. Time was integrally linked with the theme of environmental responsibility, as many respondents referenced time in terms of availability of resources for future generations. Others stressed duration and continuance in general, with resources "continuing 
over time without being depleted. That there is a balanced ecosystem, something that can continue over a long period", linking environmental responsibility today to enduring availability, a concept that is discussed in the next section.

Respondents' time spans ranged from generational to millennial, to perpetual, as in the following response: "Well, sustainable, I guess means, you know that you can keep going for thousands of years. It's not going to take up resources that you can't renew again". These multi-generational timescales suggest that the idea of time in relation to sustainability also relates to the economic concept of discounting. Not only is the theme of time explicit in the reference to supplies lasting for future generations, but also in the concept of renewal in perpetuity. Thus, several respondents went beyond the thousand-year time horizon to suggest that sustainable means "forever", "ad infinitum" or "indefinitely". In doing so they assume that human action can achieve a systemic equilibrium, and do not account for ecological evolution, shocks and perturbations, and other ecosystem dynamics which may affect the abundance of resources regardless of human consumption or other sustainability actions.

\subsubsection{Perpetual Availability}

The concepts of environmental responsibility over time ultimately led several respondents to the idea that natural resources will be perpetually available within a sustainable yield. One Londoner said, "it means that there is a plentiful amount of fish in the sea, that there is still enough to take away for our consumption and that there is enough readily available..." Others captured the idea by saying things like "it can be continuously sourced or it can be replenished easily". Or "It [sustainable] means that it's something that I can buy now, and if I come back in ten years' time it will be the same quality and quantity". Others simply said sustainable means, "that it won't run out". Significantly this concept of perpetual availability mirrors the fisheries management paradigm of Maximum Sustainable Yield (MSY). However, this paradigm has been criticized for its failure to go beyond single species production models, or to incorporate panarchy, or the interplay between environmental change and persistence as a result of anthropogenic or other drivers $[43,44]$. For consumers there is an assumption that as long as we are environmentally responsible over time, we can continue to have the same things in the same proportions that we have always enjoyed. Given that most wild-capture fisheries are overexploited and that demand for fish is growing with population increases, this lack of accounting for ecological limits places unreasonable expectations on the future availability of wild-capture fish stocks.

\subsubsection{Use}

As noted above, inherent in most respondents' description of sustainable is the concept of use. Respondents assume that if consumers are environmentally responsible over time with their purchase of seafood products then they can expect to use these products indefinitely in the future. That use, in some cases explicitly described as "consumption", is thus framed as an active, positive contribution to sustainability. As one London respondent said, "I'm not doing significant harm by eating it". Others put it more simply as: "[sustainable is] not overusing". As one Washington, DC respondent summed it up: "[sustainable is] use of a resource that is responsible to the environment and society". 


\subsubsection{Production}

Several respondents made explicit references to production methods or the means of production. These references ranged from general comments about what they considered to be sustainable production methods, often using terrestrial agricultural analogies, such as leaving fields fallow or, in forestry, cutting down a tree and planting a new one in its place. A few respondents specifically mentioned fisheries related methods, such as using the "right net".

The production process for some was viewed as a chain of actions or as one person put it, again from a terrestrial perspective: "producing food in a way that preserves the land, workers, supply chains. [It's] produced and distributed and contributes to the health of people and planet". That is, the chain of actions for something to be sustainable started with the production of the product.

Many respondents viewed the concept of production from a utilitarian perspective, conceptualising sustainable as "food that is produced in a manner that promotes on-going supply", or a product that is "produced in a way and at a price that a producer can make a living". One respondent, whose brother was a cattle farmer, talked specifically about the need to sustain the producer, stating that "if you have too much emphasis on environmental issues, you make it difficult to make a living". She was very sceptical of certain environmental issues, such as climate change, but she drove a great distance each week to get her fish from the local port, since she trusted the produce more than the local supermarket. Further, she made an effort to know her local abattoir as she was very concerned about animal welfare and wanted to ensure her meat came from humanely treated animals. So, while she might have articulated a concept of sustainability in relation to the economic survival of the producer, her actions were likely closer to the idealized concepts of a "sustainable" or "ethical" consumer intimately aware of the production methods and making more sustainable consumption decisions as a result.

\subsubsection{Avoiding Depletion or Adverse Environmental Impact}

Avoiding depletion or adverse environmental impact was a theme frequently emphasised. An Oxford Farmers' Market respondent painted a very vivid description of what sustainable meant to her.

"I suppose sustainable means that you don't deplete it to the point where it's kind of nutrition-less or just gone. With sustainable fishing, it means you have to leave some fish to have baby fish left in the sea. Otherwise, you just wipe them out. For, sustainable vegetables you have to leave some nutrients in the soil. In olden times you leave a field fallow, then it would increase its nutrients and then you might rotate. There is nothing of that anymore. If you don't have nutrients, you spray them on. You add it in different ways. It's not sustainable. It's almost, not like depleting stuff, that's what sustainable means to me. I don't know if that's right or not".

This respondent employs some of the earlier discussed themes of environmental responsibility and agricultural analogy in production methods in order to have sustainable products. She also indicates that we do not currently have adequate methods to ensure sustainability. Others echoed her connection of production methods and depletion, such as this respondent who said sustainable means, "a practice that doesn't deplete the earth or the producers in a bad way; that producers and the Earth aren't unduly 
impacted by the production method". In this articulation, it's as if the method of production is responsible for the depletion independent of those who carry out the work.

Several respondents' used language like "endangering it", making it "go extinct" or exploiting the resource so that "it won't quite expire before it should", when defining sustainable. Embedded in these concepts of non-depletion is an emphasis on human action. That is to say, that to be sustainable requires sustainable behaviour on the part of both the producer and the consumer to avoid adversely impacting the Earth and its inhabitants.

In addition to the idea of depleting, exploiting, or extirpating a particular natural resource, respondents also talked more generally about "impacting the environment". For example, one respondent said sustainable is, "to be able to produce into the future without negative impacts to the environment". Others described sustainable as having little-to-no impact or no appreciable impact.

\subsubsection{A Balanced System}

Ultimately, many of respondents described sustainable as being a balance between the production methods, the environment and our use. Sustainable is "about maintaining a status, a balance, maintaining an environment of balance that will allow any system to function fruitfully for an indefinite period of time". Another said, "Keeping a balance. I fish, so not overfishing, making sure that the item doesn't become scarce as a result of consumer use". Two respondents in Washington, DC posited that a sustainable system is a "closed system", where the "inputs equal the outputs". The concept of balance carries with it a sense of equilibrium in the environmental system. Most of the consumers also referred to balance in temporal-environmental terms, extracting enough for present needs without compromising the needs of future generations. Only one respondent said sustainable meant "maintainable, affordable in business terms", directly invoking an economic sustainability perspective. More commonly, respondents viewed sustainability in broad economic terms, for example equating it with "sustainable environmental practices, sustainable markets, diversified markets, [and] a consistent supply and demand".

\subsubsection{Reliable/Quality}

Significantly, few respondents mentioned the idea of quality. When raised as a theme, respondents emphasized that it is important that "sustainable" not be seen as a trade-off for a lesser good. Some underscored that quality lies in the context of the product, for example that it is "fresh, more lasting". Others said sustainable "means to me that good food is producible in the longer term". And others employed ideas of health, such as that a product is "dependable in health terms", "prepared properly to eat", and "without antibiotics and pesticides", as metrics of quality. Also captured in the idea of quality is a sense of trust, as evidenced in terms like "trustful food" or "trustworthy". One respondent, who was from the UK but interviewed in Washington, DC, summed up "sustainable" as "produced in a way and at a price that the producer can make a living. Of good quality is implicit in it, as is reasonable animal welfare", adding the dimension of quality in relation to the sustainable production method. 


\subsubsection{Don't Know}

As might be expected, some respondents were not able to easily articulate what "sustainable" meant to them. A transplanted Canadian in London, said "I write articles on this, I should be able to define it", and then continued to wonder aloud as to how best to define it. A psychoanalyst in DC's first response was "I am really smart; I should be able to define this", before graspingly offering her understanding.

Of those who did not respond at all, the vast majority did not speak English as their first language and were not native to the city in which they were interviewed. Another portion of those sampled provided a response to what sustainable is but wondered aloud if it should include other dimensions, such as social or economic impacts, as opposed to just environmental ones, akin to the so-called "triple bottom line" [45]? Finally, others suggested only vague sentiments, as in, "I know what it means but I can't put it into words, can't think of it, trusting maybe?" These responses suggest that the concept retains a certain common sense yet ineffable quality, making it hard to define.

\section{Discussion}

In the idealized behaviour model of seafood eco-labelling, described in the introduction, consumers' purchases play a critical role in incentivizing sustainable fisheries. This model, however, is contingent on consumer awareness and understanding of sustainability, as well as their awareness of environmental and social issues surrounding capture fisheries. This study demonstrates that respondents in Washington, DC and London generally report considering environmental impact when purchasing their seafood and report a high recognition and purchase level of seafood products with eco-labels or environmental claims. Of the Washington, DC respondents $87.2 \%$ had seen one or more of the seafood eco-labels or environmental claims in the survey and that $76.7 \%$ of those consumers had purchased one or more. In London, $72.5 \%$ of the respondents reported seeing one or more of the eco-labels and $60 \%$ of those purchased one or more. Of the labels shown, dolphin-safe and organic were the most recognized and purchased in both samples. Given that the dolphin-safe label and the organic label have been in the market place for nearly two decades it is not surprising that these were the two most recognized labels in this survey.

If the dolphin-safe and organic responses are not considered, then consumer recognition of one or more labels drops to $40.7 \%$ in Washington, DC and 52.5\% in London. Those reporting purchasing one or more of the remaining labels drops even further to $30.2 \%$ in Washington, D.C., and $43.8 \%$ in London, England; indicating that consumers are less familiar with other labels.

As we lay out in the logic model, the first assumption is based on consumers' understanding of what is a sustainable fishery. The dolphin-safe label has been surrounded by a very public media campaign to show the impacts of setting purse seine fishing nets on a highly identifiable and charismatic marine mammal. Yet even here consumers can be led to understand sustainable as dolphin safe fishing techniques regardless of the status of tuna stocks or other ecosystem impacts. There are few seafood eco-labels that clearly depict the sustainability issues of a fishery in a way that can be easily understood by the consumer. Given the multitude of issues impacting the sustainability of fisheries, from over capacity to overfishing to illegal fishing to fishers' working conditions to bycatch (as in the dolphin safe 
case) and habitat impacts, it is difficult to distil these issues into a single iconic representation or sustainability signal.

On balance, then, the original model's assumption that consumers play an influential role in incentivizing sustainable fisheries through their purchases is largely unsupported [16]. However, that doesn't mean that consumers can't play a role in incentivizing more sustainable fisheries, rather there may be more direct means than through their purchases.

When placing this analysis in the context of consumers' articulation of what sustainable means, high level of awareness of eco-labels and environmental claims exists as well as a general concept of sustainable. Only six of the respondents in the London sample could not offer their explanation of it, and in those cases English was not their first language. Likewise in the Washington, DC sample, seven of the respondents were not able to offer an explanation, five of whom did not speak English as their first language. The vast majority of the respondents could offer an explanation if not a concise definition. Consumers articulated "sustainable" as embodying critical dimensions of environmental responsibility, intergenerational time, perpetual availability, prudent use, safe production, avoided depletion, a balanced system, and a reliable/quality product. The typical articulation could be summarized as "sustainable products are there to be used over the long term without harming the Earth, but that human action is required by producers and consumers to ensure they are sustainable".

With less than two hundred respondents covering two capital cities, this study offers insight into consumers' articulation of sustainability, but cannot be considered a fully representative study. Further, surveys like this often have to contend with the social desirability effect of the respondent indicating more socially acceptable or prestigious responses versus what they actually believe or do. In this case, it is possible that some respondents indicated having seen an eco-label because they felt that was the socially acceptable answer. However, this was mitigated to some extent by ending the survey with a qualitative question that required the respondent to describe in their own words what sustainable meant to them. Respondents were thus compelled to give their own interpretation of sustainability independent of any pre-selected answers that might give clues to as the socially desirable answer.

Further, these results comport with other studies on consumers' understanding of what is sustainable. Hanss et al. conducted in Norway 123 face-to-face interviews with participants encountered in public places [41]. This study looked at whether participant's responses would encompass the five dimensions of sustainability that they proposed-environmental, social, economic, temporal and developmental. They then asked the participants to indicate how frequently they had seen 19 product labels and then rate them on their sustainability. The environmental aspects of sustainability were most frequently discussed, along with the social and developmental. Participants in this study discussed temporal and economic aspects of sustainability the least. They found that consumers' perception of how indicative the label is of a sustainable product was positively related to their familiarity with the label. Grunert et al. also studied consumers understanding of sustainability and eco-labels and asked them to explain what sustainable meant in their own words [46]. They found that of the 4408 respondents in the UK, France, Germany, Spain, Sweden and Poland, those respondents from Germany, France, Spain and the UK related sustainable to environmental protection while Poland linked it to maintaining a standard of living. Further, when given a list of 18 items to choose from that relate to sustainability, the respondents more often choose those relating to environmental sustainability than social sustainability. Their study also looked at the use of several sustainability labels, but for non-seafood products. They concluded that a 
general concern for sustainability does not directly lead to changes in behaviour even with readily available information [46]. Our study adds to this growing literature on consumers' perceptions of what is sustainable $[41,46]$ and connects to cultural models of what sustainability is and how to incentivize sustainable fisheries.

Consumers surveyed here clearly relate sustainability to environmental responsibility and recognize that being sustainable takes some action on their part, often through their act of consuming/purchasing goods. This supports the first assumption of the idealized model that a segment of consumers want to buy sustainable products. However, it's not clear that eco-labels or environmental claims by themselves enable consumers to understand how their seafood is produced sustainably. Apart from the dolphin-safe label, the other labels cover multiple fisheries from around the world and grant certification based on different criteria.

Generic seafood sustainability labels may not convey sufficient meaning to compel action, since consumers may fail to connect their purchases to contributing to a more sustainable fishery. As Eden suggests: assurance schemes have become "knowledge intermediaries" in the effort to reconnect consumers with producers. However, such assurance schemes are in themselves not a "knowledge-fix", as information is not a "one-way flow" but rather it can be "re-interpreted, validated, received, resisted and outright ignored" [19]. While a segment of consumers may want to buy sustainable seafood products, it's not clear that eco-labels and environmental claims covering a multitude of sustainability issues by themselves enable consumers to do so easily. Consumer driven demand of eco-labels is not occurring on a large scale; rather eco-labels may rather serve as a means for a business to reduce brand risk $[5,16]$.

As noted in the introduction section, when more labels enter the market, consumers need to have enough information to understand these labels [17], but not too much information to confuse them [11]. This has caused some to advocate for a standardized label [41], possibly set by government [47]. However in this survey, $50 \%$ of those sampled in each city did not know who was in charge of managing commercial fisheries in their country. If a standard was to be set by a government entity then significant education and outreach to consumers would need to be undertaken about the issues surrounding the status of fisheries, who regulates the fisheries, and what the standard means for sustainability.

The recent emphasis to promote eco-labels without presenting the larger context of fisheries management domestically and globally has made eco-labels an end instead of a means. Eco-labels should be a means, not an end for consumers to try to support those fisheries moving towards more sustainable approaches to fishing. In our opinion, it is more efficient and impactful to educate consumers about what makes a fishery sustainable and what sustainable seafood consumerism means. In doing so consumers' understanding of sustainable, which is one based on an active concept of environmental responsibility, may be deepened. Consumer education and engagement with sustainable fisheries needs to evolve beyond buying the "right" fish to include demanding that the fishing industry and their government improve fisheries management and retailers only provide sustainable seafood options. Ultimately, sustainable seafood should be the only option for consumers to purchase in stores. While eco-labels and environmental claims can possibly aid consumers in their efforts to consume sustainably, if we focus on educating consumers about eco-labels and not the underlying structural problem of overfishing an opportunity is missed to build a constituency that both supports sustainable seafood through their purchases but that also demands it from the fishing industry, retailers and governments. The Sustainable Seafood Movement's emphasis on market-based approaches has focused on the public's role as 
consumers, rather than motivating citizens $[32,38]$. Both of these roles need to be engaged so that consumers demand sustainable seafood in the marketplace, as well as the electoral space.

\section{Conclusions}

Consumers surveyed in Washington, DC and London, England $(n=166)$ had a high recognition of issue-specific eco-labels such as, organic and dolphin-safe. These eco-labels have been established longer and focus on well-known ecological issues, whereas other eco-labels address a range of sustainability issues. Labels like MSC or Friends of the Sea, which deal with a multitude of sustainability issues across numerous fisheries, give all products they certify the same consumer-facing label. Thus, consumers do not gain a deeper understanding of the sustainability issues in any particular fishery. As Eden has argued, these labels don't improve consumer understanding of the resource ecology or production process, but rather act a proxy [19].

Akenji has added to that criticism, by arguing that eco-labels promote green consumerism, not sustainable consumption, as consumers assume that buying something labelled sustainable is sustainable, when instead, they may need to evaluate their level of consumption [48]. Consumers interviewed and surveyed here articulated sustainability as being a concept that required action by both the consumer and the producer. This case study demonstrates that these consumers do have an understanding of what is sustainable, but that beyond the organic and dolphin-safe labels it is not clear that eco-labels are resonating with consumers and thus activating their role in incentivizing sustainable fisheries. While some certification programs have played a role in improving fisheries sustainability and possibly aided interested consumers [49], a greater emphasis should be placed on activating the public's role not just as consumers, but also as citizens too [32]. While efforts have been made to conduct public outreach campaigns, further investigation is still needed as to how to better engage the public as consumers and as citizens to improve the stewardship of wild capture fisheries [50,51].

\section{Acknowledgments}

Thank Kersty Hobson, Connie McDermott and Dave Favis-Mortlock for reading the early drafts of this article and providing critical comments to improve the article. Thank Kashef Majid for reading several versions and providing advice on the quantitative sections.

\section{Author Contributions}

The first author designed the interview and survey format with input from the second author. The first author conducted all of the data collection and analysis. The second author provided detailed input on all aspects of the manuscript preparation.

\section{Conflicts of Interest}

The authors declare no conflict of interest. 


\section{References}

1. Seafood Ecolabelling Principles and Practice; Ward, T., Phillips, B., Eds.; Blackwell Publishing Ltd.: Singapore, 2008.

2. Trenor, C.; Mitchell, J. Carting Away the Oceans 7; Greenpeace: Amsterdam, The Netherlands, 2013; pp. 1-49.

3. Worm, B.; Hilborn, R.; Baum, J.K.; Branch, T.A.; Collie, J.S.; Costello, C.; Fogarty, M.J.; Fulton, E.A.; Hutchings, J.A.; Jennings, S.; et al. Rebuilding global fisheries. Science 2009, 325, 578-585.

4. Hilborn, R.; Hilborn, U. Overfishing: What Everyone Needs to Know; Oxford University Press: New York, NY, USA, 2012.

5. Gulbrandsen, L. Creating markets for eco-labelling: Are consumers insignificant? Int. J. Consum. Stud. 2006, 30, 477-489.

6. Potts, T.; Brennan, R. Sustainable Seafood and Eco-labelling; Scottish Association of Marine Science: Oban, UK, 2011; pp. 1-78.

7. WWF. FIP Handbook; WWF: Gland, Switzerland, 2013; pp. 1-86.

8. Pieniak, Z.; Vanhonacker, F.; Verbeke, W. Consumer knowledge and use of information about fish and aquaculture. J. Food Policy 2013, 40, 25-30.

9. Potts, T.; O’Higgins, T.; Mee, L.; Pita, C. Public Perceptions of Europe's Seas; KnowSeas Project: Oban, UK, 2011; pp. 1-23.

10. Monterey Bay Aquarium. Available online: http:// www.Seafoodwatch.org (accessed on 14 November 2014).

11. Hallstein, E.; Villas-Boas, S.B. Can household consumers save the wild fish? Lessons from a sustainable seafood advisory. J. Environ. Econ. Manag. 2013, 66, 1-20.

12. Uchida, H.; Onozaka, Y.; Morita, T.; Managi, S. Food policy. J. Food Policy 2014, 44, 68-76.

13. Eden, S.; Bear, C.; Walker, G. Understanding and (dis)trusting food assurance schemes: Consumer confidence and the "knowledge fix". J. Rural Stud. 2008, 24, 1-14.

14. Schmitt, C.V. Fishing: Adrift in a sea of information about sustainable seafood. Maine Policy Rev. 2011, 20, 1-9.

15. Roheim, C.A. An evaluation of sustainable seafood guides: Implications for environmental groups and the seafood industry. Mar. Resour. Econ. 2009, 24, 301-310.

16. World Economic Forum (WEF). More with Less: Scaling Sustainable Consumption and Resource Efficiency; WEF: Cologny, Switzerland, 2012; pp. 1-44.

17. Ben Youssef, A.; Abderrazak, C. Multiplicity of eco-labels, competition, and the environment. J. Agric. Food Ind. Organ. 2009, 7, doi:10.2202/1542-0485.1271.

18. Brécard, D. Consumer Confusion over the Profusion of Eco-Labels; University de Nantes: Nantes, France, 2012; pp. 1-25.

19. Eden, S.; Bear, C.; Walker, G. Mucky carrots and other proxies: Problematising the knowledge-fix for sustainable and ethical consumption. GEOFORUM 2008, 39, 1044-1057.

20. Roheim Wessells, C.; Anderson, J.G. Consumer willingness to pay for seafood safety assurances. J. Consum. Aff. 1995, 29, 1-23. 
21. Roheim Wessells, C. The economics of information: Markets for seafood attributes. Mar. Resour. Econ. 2002, 17, 153-162.

22. Johnston, R.J.; Roheim, C.A. A battle of taste and environmental convictions for ecolabeled seafood. J. Agric. Resour. Econ. 2006, 31, 283-300.

23. Roheim, C.A.; Asche, F.; Santos, J.I. The elusive price premium for ecolabelled products: Evidence from seafood in the UK market. J. Agric. Econ. 2011, 62, 655-668.

24. Sogn-Grundvåg, G.; Larsen, T.A.; Young, J.A. The value of line-caught and other attributes: An exploration of price premiums for chilled fish in UK supermarkets. Mar. Policy 2012, 38, 41-44.

25. Brécard, D.; Lucas, S.; Pichot, N.; Salladarré, F. Consumer preferences for eco, health and fair trade labels. J. Agric. Food Ind. Organ. 2012, 10, 1-32.

26. Brécard, D.; Hlaimi, B.; Lucas, S.; Perraudeau, Y.; Salladarré, F. Determinants of demand for green products: An application to eco-label demand for fish in Europe. Ecol. Econ. 2009, 69, 115-125.

27. Jaffry, S.; Pickering, H.; Ghulam, Y.; Whitmarsh, D.; Wattage, P. Consumer choices for quality and sustainability labelled seafood products in the UK. Food Policy 2004, 29, 215-228.

28. Walmart Walmart Takes Lead on Supporting Sustainable Fisheries. Available online: http://www.walmartstores.com/sustainability (accessed on 15 July 2013).

29. Target Target Sustainable Products. Available online: http://www.corporate.target.com/corporateresponsibility/environment/sustainable-products (accessed on 24 February 2014).

30. Clark, G.L.; Hebb, T. Why should they care? The role of institutional investors in the market for corporate global responsibility. Environ. Plann. A 2005, 37, 2015-2031.

31. Baird, I.G.; Quastel, N. Dolphin-Safe tuna from California to Thailand: Localisms in environmental certification of global commodity networks. Ann. Assoc. Am. Geogr. 2011, 101, 337-355.

32. Jacquet, J.; Hocevar, J.; Lai, S.; Majluf, P.; Pelletier, N.; Pitcher, T.; Sala, E.; Sumaila, R.; Pauly, D. Conserving wild fish in a sea of market-based efforts. Oryx 2009, 44, 45.

33. Froese, R.; Proelss, A. Evaluation and legal assessment of certified seafood. Mar. Policy 2012, 36, 1284-1289.

34. MSC. Net Benefits: The first ten years of MSC Certified Sustainable Fisheries; MSC: London, UK, 2009; pp. 1-37.

35. Karlsen, K.M.; Hermansen, O.; Dreyer, B.M. Eco-labeling of seafood Does it affect the harvesting patterns of Norwegian fishermen? Mar. Policy 2012, 36, 1123-1130.

36. Bush, S.R.; Toonen, H.; Oosterveer, P.; Mol, A.P.J. The "devils triangle" of MSC certification Balancing credibility, accessibility and continuous improvement. Mar. Policy 2012, 37, 288-293.

37. Agnew, D.J.; Gutiérrez, N.L.; Stern-Pirlot, A.; Smith, A.D.M.; Zimmermann, C.; Sainsbury, K. Rebuttal to froese and proelss "evaluation and legal assessment of certified seafood". Mar. Policy 2012, 38, 1-3.

38. Konefal, J. Environmental movements, market-based approaches, and neoliberalization: A case study of the sustainable seafood movement. Organ. Environ. 2013, 26, 336-352.

39. Olson, J.; Clay, P.M.; da Silva, P.P. Putting the seafood in sustainable food systems. Mar. Policy 2013, 43, 1-8.

40. MAFAC. Marine Fisheries Advisory Committee. Available online: http://www.nmfs.noaa.gov/ ocs/mafac/ (accessed on 17 November 2014). 
41. Hanss, D.; Böhm, G. Sustainability seen from the perspective of consumers. Int. J. Consum. Stud. 2011, 36, 678-687.

42. MSC. MSC Consumer Survey 2012; MSC: London, UK, 2012.

43. Finley, C. Finley, Carmel-2010-The socieal construction of Fishing-ES-2008-2704(1). Ecol. Soc. 2009, 14, 1-14.

44. Panarchy: Understanding Transformations in Human and Natural Systems, 2nd ed.; Gunderson, L.H.; Holling, C.S., Eds.; Island Press: Washington, DC, USA, 2002.

45. Elkington, J. Cannibals with Forks; New Society Publishers: Gabriola Island, BC, Canada, 1997.

46. Grunert, K.G.; Hieke, S.; Wills, J. Food policy. J. Food Policy 2014, 44, 1-13.

47. TheFishSite EU Must Overhaul Fisheries Eco-Labelling, says MEP. Available online: http://www.thefishsite.com/fishnews (accessed on 6 January 2014).

48. Akenji, L. Consumer scapegoatism and limits to green consumerism. J. Clean. Prod. 2013, 63, 1-11.

49. Gutiérrez, N.L.; Valencia, S.R.; Branch, T.A.; Agnew, D.J.; Baum, J.K.; Bianchi, P.L.; Cornejo-Donoso, J.; Costello, C.; Defeo, O.; Essington, T.E.; et al. Eco-Label conveys reliable information on fish stock health to seafood consumers. PLoS One 2012, 7, e43765.

50. Fletcher, S.; Potts, J.S.; Heeps, C.; Pike, K. Public awareness of marine environmental issues in the UK. Mar. Policy 2009, 33, 370-375.

51. Steel, B.S.; Smith, C.; Opsommer, L.; Curiel, S.; Warner-Steel, R. Public ocean literacy in the United States. Ocean Coast. Manag. 2005, 48, 97-114.

(C) 2014 by the authors; licensee MDPI, Basel, Switzerland. This article is an open access article distributed under the terms and conditions of the Creative Commons Attribution license (http://creativecommons.org/licenses/by/4.0/). 